\title{
Identity and sovereignty in the regional system
}

The divergence of identity and territory: retarded nation-building?

In the Westphalian model that European expansion ostensibly globalised, a relative congruence between identity and sovereignty, between nation and state, endows states and the states system with legitimacy. Social mobilisation creates, in modernising societies, receptivity to identification with larger communities - nations potentially coterminous with a state; in an age of nationalism, such identity communities seek a state and state leaders seek to forge a common national identity among their populations. Where the drive to bring state and nation into correspondence is obstructed, irredentist conflicts tend to destabilise regimes and foster inter-state conflict. Nowhere is the divergence of identity and state sharper than in the Middle East. There popular identification with many individual states has been contested by strong sub- and supra-state identities, diluting and limiting the mass loyalty to the state typical where it corresponds to a recognised nation (Ayoob 1995: 47-70; Hudson 1977: 33-55).

Historically, identification with the territorial state has been weak, with popular identify tending to focus on the sub-state unit the city, the tribe, the religious sect - or on the larger Islamic umma (Weulersse 1946: 79-83). This is because states, the product of outside conquerors, imported slave-soldiers without local roots, or religio-tribal movements, typically disintegrated after a few generations and when a new wave of state-building came along the states' boundaries were often radically different. Moreover, in an arid environment of trading cities and nomadic tribes, peoples, notably the Arabs, lacked the defined sense of territorial identity and attachment 
to the land associated with peasant societies. The important exceptions, those societies with substantial peasantries - Turkey, Iran and Egypt - are those where contemporary states most closely approximate national states.

Aggravating the situation was the way the contemporary states system was imposed at the expense of a pre-existing cultural unity deriving from centuries of rule by extensive empires ruling in the name of the Islamic umma. Where, historically, a common suprastate identity had embraced local communities and a mosaic of identity groups around an imperial centre, Western imperialism's creation of artificially bounded states divided the region into a multitude of competing state units. Instead of the natural processes of sorting out boundaries through war and dynastic marriage which took place in the northern world, the boundaries of the modern Middle East state system were arbitrarily imposed and frozen by the Western powers according to their own needs, not indigenous wishes (Ayoob 1995: 33). This process disrupted a multiplicity of regional ties while reorienting many economic and communications links to the Western 'core'. In reaction, new supra-state ideologies, expressive of the lost cultural unity, were increasingly embraced: Pan-Arabism by the Arabic-speaking middle class and political Islam among the lower middle classes. Both, at various times, challenged the legitimacy of the individual states and spawned movements promoting the unification of states as a cure for the fragmentation of the recognised community. The result has been that the Arab world constitutes, in Kienle's argument, a system of territorial states, but not, so far, nation-states (Hudson 1977: 33-55; Kienle 1990: 1-30; Korany, 1988: 164-78).

At the same time, all the states of the region suffered competition from the mosaic of sub-state identities on which the state boundaries were haphazardly imposed. There are ethnic minorities in all Middle East countries, notably the Kurds, spread between Iraq, Iran, Turkey and Syria, and the Berbers, who spill across North African boundaries. Iran is the premier multi-ethnic society, its Persian core flanked by Azerbaijanis, Kurds, Turkomans, Arabs and Baluchis. Religious pluralism is even more striking: Sunni Muslims are the majority community in the Arab world, but not in particular states (Lebanon, Iraq) while Shi'a Muslims, the majority in Iran, spill across the Arab region where they are pivotal minorities or deprived majorities in Bahrain, Kuwait, Iraq, and Lebanon. Several 
Shi'a offshoots, notably the Druze, Ismailis and Alawis are historically important in Syria and Lebanon, while the Zaydis dominate Yemen. Offshoots of the purist Kharijites are to be found in Oman (Ibadies). A multitude of Christian minorities, divided by the languages of their liturgies or allegiances to Eastern Orthodoxy or Rome, are scattered across the region.

Where, as is frequent, such identity groups spill across borders - becoming 'trans-state' - the lack of correspondence between borders and identity may foster irredentism. This, in turn, may generate inter-state conflicts as states contest each others' borders or 'interfere' in each others' 'domestic' affairs by supporting irredentist groups, a practice which may escalate into actual military confrontation between states. The best example of this is the case of the Kurds who have been regularly used by their host states in their rivalries with each other and who have attempted to exploit these state rivalries in their struggle for national rights; this has regularly led to inter-state conflict, notably between Syria and Turkey and between Iran and Iraq. In Lebanon where a multitude of sects, never effectively subsumed by a common Lebanese identity, led to civil war, each warring sect sought outside patrons, thereby making Lebanon a battlefield between other states, notably Israel and Syria (Ayoob 1995: 7, 47-70; Gause 1992: 444-67).

Against this reality must be set a century of ongoing state formation. The consolidation of regimes in individual states created vested interests in the new fragmentation. State builders struggled to contain the penetration of their territory by trans-state forces and tenaciously defended their sovereignty against either a redrawing of boundaries or the sub-state autonomy that might satisfy minority demands. The individual Arab states have outlasted the Pan-Arab movements that sought a solution to the 'one nation-many states' dilemma by merging them in Arab unionist projects such as the abortive UAR between Egypt and Syria. States effectively balanced against efforts to export Pan-Arab or Pan-Islamic revolution. The insecurity of the states system spurred state formation and a greater acceptance at elite levels of mutual respect for sovereignty. Moreover, the international system, in guaranteeing state borders, obstructed Bismarkian attempts at forceful absorption of neighbouring states, such as Saddam Hussein's attempt to absorb Kuwait. Thus, the borders imposed at the birth of the state system remain largely intact. The durability of the states system does not necessarily imply the 
stability or legitimacy of the individual states which, indeed, have suffered from chronic legitimacy deficits ultimately rooted in the shallowness of popular identifications with them. If, however, the states are here to stay, as seems likely, the challenge of state-builders is to reconcile such individual statehood with popular identity.

This may, indeed, be happening for identities are plastic and that which triumphs in a state is the 'constructed' product of contestation by rival leaders and movements. State-builders who command the instruments of socialisation - mass media, mass education enjoy a decisive advantage in promoting a certain identity among the rising generation. However, it is by no means the case that all identities have equal chances of success; rather, the pre-existence of linguistic unity, facilitating social communication between elites and masses of a particular group (while obstructing it across groups), and historic memories of a common community give decisive advantage to some identities over others that may appear 'artificial', such as a 'Babylonian' identity for Iraq or the Ottomanism that ultimately proved impotent against Slavic, Arab and Turkish nationalisms having linguistic roots. Given the greater popular credibility of Arab-Islamic identity over most alternatives, rulers in the contemporary Arab states vacillate between legitimising themselves as Arab-Islamic leaders and relying on state identities; they cannot fully rely on Arabism or Islam since their borders are not congruent with the Arab or Islamic communities, and adherence to Arabism may sacrifice state interests; yet they cannot fully rely on state identities which lack sufficient credibility (Anderson 1991: 72). They may try to overcome this dilemma by 'statising' a supra-state identity as the official state ideology, as when Ba'thist Syria claims to be the special champion of Arabism or Saudi Arabia of Islam.

While the multitude of identities from which citizens can choose seems compatible with a post-modern world, the considerable extent to which this means states cannot depend on being their citizens' primary political loyalty, has pushed state-builders into authoritarian strategies. The more stable Arab states have, with few exceptions, advanced through a process of primitive power accumulation, in which authoritarian state-builders established tightly knit ruling cores through extensive use of sub-state loyalties (kin, tribe, sect) while exploiting supra-state identities - Arabism and Islam as official ideologies. But this is a vicious circle: such reliance on topdown state building has limited the mass mobilisation that was a 
crucial ingredient in the West's prototype nation-building and comes at the expense of the democratic inclusion and minority rights which could, in principle, generate a sense of common territorial citizenship from which new state-centric identities might develop. As such, most Middle Eastern states still face powerful competition for the loyalty of their citizens from both sub- and supra-state identities and these remain powerful tools for the mobilisation of opposition against state establishments. Significantly, nation-building has proceeded with most success in Turkey, Israel and Iran where indigenous state-builders were able to determine borders and ensure a rough correspondence between them and the dominant identity.

\section{Alternative identities and foreign policy}

Pan-Arab nationalism and its rivals

There was every reason why an Arab identity would be uniquely compelling for the citizens of most of the Arab states. These states, mostly successors of the Islamic Ottoman Empire, retained a cultural similarity. Most important, a common Arabic language - the critical ingredient of nationhood - existed. The 'awakening' of Arab identity was a product of the spread of mass education and literacy, especially in the 1950s and often by the Egyptian teachers recruited across the Arab world who helped form the educated middle class. The spread of a standardised Arabic in newspapers and radio made the language more homogeneous, stunting the evolution of national dialects as the linguistic basis of separate nations. The recent advent of Arab satellite TV has sharply reinforced cross-border participation in a common discourse. All this makes the Arab world, in Noble's (1991: 56) words, a 'vast sound chamber' in which ideas and information circulate widely. In addition, similar food, marriage and child-rearing practices, music and art are recognisable region-wide. Extended family ties frequently crossed borders and cross-border immigration has been constant: in the 1950s there were major flows of Palestinian refugees; since the 1970s labour migration to the Gulf oil-producing states has been substantial. Niblock (1990) argues that the interests of the separate states are too intertwined - by labour supply, investment funds, security, water, communications routes, and the Palestine issue - for them to develop self-sufficient coherence. Long after the creation of the Arab states system, Noble (1991: 57) could credibly argue that the Arab 
world was less well represented by realism's impenetrable 'billiard balls' in which governments insulated domestic society from foreign influence than by a set of interconnected organisms separated only by porous membranes.

As a result, supra-state identities - Arabism and Islam - are, for many people, more emotionally compelling than identification with the state. There is a widespread feeling of belonging to a distinct Arab World (al-'alam al-arabi). According to a 1978 survey of respondents throughout the Arab world, 78 per cent believed the Arabs constituted a nation, 53 per cent believed the state boundaries were artificial and the vast majority supported doing away with them in favour of a larger, perhaps decentralised state (Korany 1987: 54-5). Arabism is enshrined in state constitutions: Jabbour found thirteen Arab constitutions which defined the nation as the Arab nation, with only Lebanon and Tunisia referring to a Lebanese and Tunisian nationhood (Ayubi 1995: 146). Uniquely in the Arab world, not this or that border, but state boundaries in general, have been seen by many Arabs to be arbitrarily and externally imposed at the expense of Arabism, and hence lack the legitimacy and sanctity they enjoy elsewhere. At the level of formal ideology, this sentiment was manifest in the doctrines of Pan-Arab nationalism which viewed all Arabic speakers as forming a nation, the states of which ought to act in concert or be confederated, or, in its most ambitious form (as in Ba thism), be merged in a single state embracing this nation.

It is not that most Arabs adamantly reject contemporary state boundaries and even Arab nationalists have not necessarily insisted on a single Arab state. But the extreme fragmentation of the region is viewed as a divide and rule strategy by imperialism and a cause of Arab weakness. Historical memories of greatness under unity and experience that the Arabs are successful when they act together (e.g. the 1973 war and use of the oil weapon), and are readily dominated when divided, keep Arabism alive. So does the sense of common victimisation: the Crusades are part of every school boy or girl's historical world view; the loss of Palestine is seen as a common Arab disaster; and the 1967 war shamed all Arabs, not just the defeated front-line states. In the 1990s, the suffering imposed on Iraqis by the Western economic sanctions was not seen as the affliction of another nation which, however regrettable, was not the business of Syrians or Tunisians, but as humiliation and pain inflicted on members of 
the same community. On the other hand, the relative success of Arab armies in the 1973 war inspired solidarity across the region and all Arabs shared Lebanon's euphoria at Israel's evacuation of southern Lebanon under Hizbollah pressure in June 2000.

As against these Pan-state sentiments, there have always been territorial fault lines in the region which could potentially underlie identities supportive of territorial-based (as opposed to linguistically or ethnically-based) separate nations. Harik (1987: 19-46) argued that a viable basis of statehood (or even nationhood) exists in a multitude of geographical entities with distinct historical experiences: where minority sects established autonomous regimes (Yemen, Oman, Lebanon); where tribal or tribal-religious movements founded regimes (Saudi Arabia); where Mamluk elites achieved autonomy as Ottoman power declined (Tunisia, Algeria). The Western imposition of the contemporary state system on these 'proto-nations', defining permanent boundaries that protected them from absorption and, endowing them with ruling elites and state apparatuses, crystallised their individuality.

The result is that multiple levels of identity co-exist in varying ways, from cases where identification with the separate states overshadows without wholly displacing Arabism to those where state identities remain subordinate to the sense of being an Arab. At the first end of the continuum is an oil city-state such as Kuwait where Farah's study (1980: 141-2) found state identification came first (24.3 per cent), then religious affiliation (14.4 per cent) and Arabism last. If Kuwait were acknowledged to be a mere part of the Arab nation, then Kuwaiti oil would be an Arab patrimony to be equitably shared with other parts of the Arab nation, not least the legions of Arab expatriates working in Kuwait. The geographically separate Maghreb has always identified less with Arab nationalism than local statehood. Some Tunisian writers defend the idea of a distinct Tunisian nation and Morocco has a long history under an independent dynasty (Ayubi 1995: 144). Yet in the 1973 Arab-Israeli war Morocco's pro-Western ruler thought it to his domestic advantage to send a contingent of troops to the far-off Syrian front; and the strong reaction in the Maghreb to the 1991 Western attack on Iraq showed that Arab-Islamic identities remain powerful, if usually latent.

In Egypt where a strong sense of territorial identity is based on the Nile valley and a history of statehood predating the Arabs, theorists such as Louis Awad contrast the 'reality' of an Egyptian nation 
with the 'myth' of an Arab nation (Ayubi 1995: 144). Yet Egyptian identity is Arab-Islamic in content, and attempts to construct alternative definitions of Egyptianness - -'Pharaonic' or 'Mediterranean' - have failed. Thus, even in the late 1970s when Egypt was withdrawing from Pan-Arab commitments and engaged in bitter disputes with other Arab states, a survey of high-status Egyptians (normally less receptive to Arabism) indicated that, although 71.3 per cent identified with Egypt first, 71.1 per cent said Egypt was a part of the Arab nation, indeed the natural leader of the Arabs (Hinnebusch 1982: 535-61). This strong sense of kinship with the Arab world meant that decisions taken purely on grounds of state interest - Egypt's separate peace with Israel, membership in the Gulf War coalition - which would be perfectly natural were Egypt a consolidated nation-state, were extremely controversial and probably damaging to regime legitimacy.

In many Mashreq cases, where externally imposed borders corresponded to no history of independent statehood, much less nationhood, Arabism was the dominant identity. It is no accident that the main Pan-Arab nationalist movement, Ba'thism, was born in Syria, and was most successful there and in Iraq and Jordan. If the natural geo-historical unit, bilad ash-sham (historic and geographical Syria), might have supported a viable nationhood, its artificial fragmentation into four mini-states prevented the truncated rump from becoming a strong uncontested focus of identity; the attempt to generate a non-Arab Syrian national identity by the Syrian Social Nationalist Party came to nothing, although when a Pan-Syrian identity is defined as Arab in content, it carries resonance. In Iraq, the opposite case of an artificial state constructed by throwing rival communal groups together, Arabism was embraced by some as the only satisfying solution.

Inter-Arab politics amidst supra-state identity: the contest of PanArabism and state sovereignty

The power of supra-state identity and the absence of nation-states arguably makes for a different, even unique, kind of regional system in the Arab core of the Middle East. Rather than an international system of self-contained national communities whose borders distinguish between 'us' and 'them', the Arab world might better be seen as an 'overarching Arab polity' within which the individual states constitute a set of semi-permeable autonomous units (Kienle 
1990: 9, 27; Sela 1998: 9-10). Yet, these units are sovereign and the supra-state community, lacking a common centralised authority, is 'anarchic'. Combining sovereignty with shared identity and norms, this system is closer to Bull's (1995) 'international society', than to an 'international system' defined merely by mutual vulnerability and insecurity; but supra-state identity in the Arab world is arguably stronger than in Bull's Western-inspired model. In such a system, where sovereign states are embedded in a supra-state community, state actors arguably must respond both to the competitive dynamics of the state system and to the norms deriving from shared identity (Barnett 1998: 10-11; 25-7).

In this system, as constructivist Michael Barnett (1998) argues, shared Arab identity infuses the content of the foreign policy roles which states assume and generates norms that constrain state sovereignty. The core issues that define Arabism are rejection of Western domination, defence of the Palestine cause, the desirability of Arab unity, and the expectation that the Arab states should act in concert in world politics in defence of all-Arab interests. Because the actions of one state regarding common Arab issues affects them all, all have an interest in participating in the definition of all-Arab interests and norms through Arab collective institutions such as the Arab League and the Arab summit system (Barnett 1998: 2, 7; Sela 1998: 12; Thompson 1970).

Yet, just because the Arab world has made up a single political arena, region-wide inter-state conflict has been endemic. Because boundaries lacked the impenetrability or sanctity of the Westphalian system, with ideological influences and trans-state movements readily crossing state lines, each state was highly sensitive to and vulnerable to the actions of others. In this context, aspirations for PanArab leadership were realistic and rivals had an incentive to manipulate trans-state ideological appeals in ways that would be ineffective and viewed as a violation of sovereignty in a conventional states system. The game was played by ideological or symbolic competition in which leaders ambitious for Pan-Arab leadership, trumpeting their own Arab credentials and impugning those of rivals, sought to sway public opinion and to mobilise the Arab 'street' to pressure (even overthrow) rival governments from below. The effectiveness of such cross-border appeals to the populations of other states was itself testimony to the existence of common identities and norms transcending borders. 
Such a unique context should make the conduct of inter-Arab politics qualitatively different from international politics, but how far this is so is a matter of controversy between constructivists and realists like Stephen Walt who, in his classic realist study, The Origin of Alliances (1987), insists that the region demonstrates the universality of realist rules. For him, Arabism was not a constraint on sovereignty but an instrument of power used, much like an army, by stronger states pursuing their 'national interests' against weaker ones. The reality is, however, far more complex than this and there is evidence that inter-Arab state behaviour has departed in key ways from that typical in a conventional states system.

Inter-Arab competition was intense, but it was quite different from a conventional 'realist' power struggle. It was not chiefly over territory or other tangibles but over the desired normative order of the Arab system. Crucially, the typical currency in this struggle - in stark contrast to that between the Arab and non-Arab Middle East - was not military power but ideological appeal: it was legitimacy, derived from being perceived to observe the norms and play roles grounded in Arabism, which gave the power to affect outcomes (Barnett 1998: 2, 6, 16; Noble 1991: 61). The struggle over the Baghdad Pact was not resolved by the distribution of military power but by Nasser's winning the normative debate over the desired regional order (Barnett 1998: 16). Nasser's blessing was sought and his censure feared not because of his army but because he was seen as the guardian of Arab nationalist norms and could bolster or subvert the domestic legitimacy of other leaders. Before Nasser, Egypt had enjoyed no such advantage over its Arab rivals and after he died, Egypt's trans-state power dissipated overnight; for while its material power had barely changed, his successor had none of the moral authority that had enabled him to make Egypt a pole of attraction for the populations of other states (Hudson 1999: 86).

To speak of a supra-state community assumes that common norms, regimes, or collective institutions, to some extent substitute for the absent common government in constraining the use of violence in political competition. In the inter-Arab game, low-level violence was part of the inter-Arab game: Arab nationalist activists who tried to subvert or overthrow governments in other states were sometimes recruited and supported by revisionist states, chiefly Nasser's Egypt; but this was a struggle over the balance of political opinion, not a contest of military forces, and arguably, such conduct 
was borderline between what would be expected in a states system and what would be acceptable in a political community.

Walt rightly argues that, even at the height of Pan-Arabism, balancing against the Egyptian hegemon was pervasive within the Arab world, at the expense of co-operation for common interests. This was practised not just by the conservative monarchies but even by ostensibly Pan-Arab regimes in Syria and Iraq when Nasser posed a threat to them. However, what he neglects is that the threat from Nasser was not military and that the balancing took the form of propaganda and, in the long run, the state-building needed to immunise regimes from Pan-Arab ideological penetration. Moreover, Pan-Arab norms did put far greater restraints on state actors than the rules of sovereignty in a Westphalian state system, excluding certain non-Arab alliance partners which might have made sense from a power-balancing perspective, notably alliances of the weaker Arab monarchies with Israel against stronger radical republics. PanArabism was initially constructed in the successful struggle to require the Arab states to adhere to a Pan-Arab collective security pact rather than a Western-dominated one (the Baghdad Pact).

Finally, Pan-Arabism was never merely a state instrument, not even of Nasserite Egypt, which most successfully exploited it. PanArab movements, trans-state in organisation and 'multi-state' in composition, were autonomous of Cairo; they used Nasser as much as he used them and they constantly pressured him into increasing his commitment to the common cause against his own better judgement. Even if Arabism was manipulated to serve the interests of states in their competition more than to advance all-Arab interests, this competition tended, Barnett argues, to establish norms of behaviour that constrained all states.

The bottom line is that the embedding of a states system in a supra-state community built an enduring tension into the Arab system between the logic of sovereignty, in which each separate state, insecure amidst the anarchy of a states system, pursues its own interests and security, often against its Arab neighbours, and the counter norm which expects states sharing an Arab identity to act together for common interests. Given this enduring rivalry between the norms of sovereignty and Pan-Arabism, what weight should be given to each was inevitably a product of contestation. Moreover, because Pan-Arab norms were themselves never fixed and had to be adapted to changing conditions, they were always open to consid- 
erable interpretation: what kinds of foreign policies were compatible with Arabism - that is, how far ties to the West were permitted, the conditions of a settlement with Israel, etc. - was never selfevident. As such, Pan-Arabism itself developed over time through what Barnett (1998: 6, 28, 40) calls inter-Arab 'dialogues'. And, as a result of this process, the balance between Pan-Arabism and sovereignty altered, swinging first against sovereignty and then back in its favour.

While the ingredients of Arab identity long existed, it was, ironically, inter-Arab leadership competition that played a central role in the overt 'construction' of Arab identity and the institutionalisation of its norms. In the 1950s and 1960s, a process of 'outbidding' took place in which rival state leaders sought to mobilise mass support by escalating the standards and radicalising the goals of Arabism. This led to demands first for more militancy toward imperialism and greater integral unity between Arab states (as embodied in the UAR and subsequent unity projects) and later for greater militancy on behalf of the Palestine cause. Once begun, this was a game that all parties had to play in order to win or retain popular support. Even status quo elites were forced to protect their domestic support against external subversion by asserting or defending their own Arab nationalist credentials (Barnett 1998: 47-52; Kienle 1990: 1-30). This provided conditions for a Pan-Arab hegemon to emerge as Nasser, having attained the status of a Pan-Arab hero, sought to institutionalise Pan-Arabism in an informal 'international regime' which laid down a foreign policy consensus on core Arab issues largely enforced by Egypt but which outlived the decline of the Egyptian hegemon by at least a decade (Jourjati 1998; Telhami 1990: 84-106).

This contest between Arabism and sovereignty was not exclusively played out at the inter-state level and a state's adoption of Pan-Arabism (or not) was in good part a result of internal power struggles. The most successful political movements inside the Arab states in the 1950s mobilised their constituents under the banner of Arabism: radical versions of Arabism were normally the ideological weapon of rising social forces with an interest in change, specifically the new middle class challenging the oligarchy in the $1950 \mathrm{~s}$. Ex-plebeian elites newly arrived in power, especially in states insecure in their separate identity or those with the potential for Pan-Arab leadership, used Pan-Arabism to legitimise their often 
precarious rule. Sovereignty, on the other hand, was the ideology of satisfied social forces, normally traditional elites on the defensive and without the potential for Pan-Arab leadership.

At a certain point, however, Pan-Arabism began an apparent decline or at least underwent a reinterpretation to the advantage of sovereignty. This 'de-construction' was, in the first instance, a result of the interaction of state leaders. Over time the competition and insecurity natural in a states system, particularly where regimes were vulnerable to trans-state subversion, reinforced the territorial differentiation between the individual states; moreover, from the beginning, those states whose sovereignty was threatened by Nasser's attempt to impose Pan-Arab uniformity formed anti-hegemonic alliances against Cairo. Also, inter-Arab rivalry, forcing competitors to act on their Pan-Arab rhetoric, 'entrapped' Arab leaders in unrealistic or risky commitments potentially costly or damaging to the interests of the individual states. This tendency climaxed in the provocative rhetoric by which Syria and Egypt blundered into the 1967 war with Israel. Once the costs of outbidding had become prohibitive and were incurred by many individual states, the scene was set for a mutual de-escalation of ideological competition. Especially after 1967, formerly radical elites, now fighting for their very survival at home, agreed with conservative counterparts to make the Arab summits system the arena for a mutual deflation of the standards of Arabism. The most portentous outcome of this was the collective legitimisation of a political settlement with Israel in return for its evacuation of the territories occupied in 1967. The normative balance started to shift from Arabism toward sovereignty, notably in the growing acceptance of the view that Pan-Arab norms had to be defined by an inter-elite consensus in which the interests of the individual states would inevitably be prioritised. The Arab summits became a system through which attempts were made to reconcile agreement on common Arab interests with state sovereignty (Barnett 1998: 40-52; Sela 1998: 3-8).

However, the much-increased insecurity issuing from Israel's overwhelming post-1967 superiority and the growing militarisation of the conflict increasingly encouraged a resort to 'self-help' among the front-line states. While this insecurity could, in principle, have issued in the strengthening of Arab collective solidarity against the common Israeli threat, the relative ineffectiveness of collective institutions stimulated, instead, the build-up of individual state capabilities and 
the individual search for diplomatic exit from war and occupation. Although this did not rule out such alliances as that between Syria and Egypt in the 1973 Arab-Israeli war, thereafter the same Egypt that had once enforced Pan-Arab standards now pioneered their sacrifice to individual state interests in its acceptance of a separate peace with Israel. This, in dramatically increasing the insecurity of other Arab states, notably Syria, encouraging them to similarly look to selfhelp through militarisation. The Iran-Iraq war had a similar effect in the Gulf. The increase in threats and in state capabilities from the arms race unleashed by these wars between Arab and non-Arab states, moreover, started to militarise inter-Arab disputes as well, and these were now more often over territory than Arab legitimacy: there were only ten such conflicts between 1949 and 1967 but nineteen between 1967 and 1989 (Barnett 1998: 203). Iraq's invasion of Kuwait marked a new order of magnitude in this tendency. In this new environment where survival depended more on raw military power than success in ideological competition, the world of constructivism was giving way to that of realism.

Finally, the 1970 s oil boom had an ambivalent but mostly deleterious effect on Arabism. On the one hand, it generated trans-state movements of labour and capital that, to an extent, integrated the Arab world; oil aid was used to heal inter-Arab conflicts, making the summit system more effective. On the other hand, oil differentiated the interests of the Arabs into rich and poor, detached the oil producers' interests from the Pan-Arab interest, and funded arms races that increased security dilemmas between Arab states. At the domestic level, oil financed a decade of state-building which made states' populations less susceptible to trans-state ideological mobilisation and allowed the formerly Pan-Arab middle classes to be co-opted by the individual states. As the Pan-Arab mobilisation of the public declined, elites were freer to put state interests over Pan-Arab interests in their foreign policies. Ironically, Pan-Arab movements were transformed into state parties and Arabism became an official ideology used to legitimise the sometimes state-centric policies of individual states.

\section{Political Islam and the international relations of the Middle East} Whether political Islam - which rose parallel with the decline of Arabism from the late 1970s - constitutes a functional substitute for Arabism as a supra-state ideology is a matter of debate. It is far from 
clear that Islam similarly detracts from the legitimacy of the individual states. Vatikiotis (1987: 42-4) argues that Islam withholds legitimacy from nationally separate states in the name of a Pan-Islamic umma and that its call for the rule of God deters the sense of national citizenship that could solidify identifications with a territorial state. Others, however, argue that Islam takes distinctive 'national' forms compatible with individual statehood as well as secularisation and democratisation (Eickelman 1998; Ibrahim 1997). Middle Eastern rulers have routinely used Islam to legitimise their regimes. To be sure, political Islam has become the main ideology of protest and Islamic movements constitute the main political opposition in most Middle East states. In some ways, just as Pan-Arabism was the ideology of the rising middle class before it acquired a stake in individual states, so political Islam is that of the marginalised petty bourgeoisie and masses who have been left out of state patronage networks, have carried the heaviest costs of the post-oil-boom structural adjustments in the region and who therefore remain susceptible to a supra-state ideology. But Islamic movements typically seek to Islamise the state, not to abolish it and arguably their objection is to the secularity of the individual states, not to their existence. Where regimes permit it, Islamists join the political process to work toward the Islamisation of public life, and states, in responding to this by Islamising their rhetoric, as well as their education, law and media, have arguably satisfied some Muslim discontent with the secular state; even when Islamists are excluded from politics, they often seek to create their own civil society - schools, welfare societies, businesses - in order to Islamise the state from the bottom up. This partial Islamisation of the state may be bringing it into greater congruence with society. In other cases, such as Syria or Algeria, regimes, battle hardened by facing down Islamic movements, now present more obdurate articles to Islamic revolution than heretofore. Facing stronger states than their Pan-Arab analogues ever did, Islamic movements have arguably been forced to concentrate on creating Islamic societies within individual states rather than seeking a Pan-Islamic order.

The impact of Islam on the international behaviour of states is even more ambiguous. Although secular Arabism and political Islam have ideologically incompatible visions of domestic order, and although the boundaries of the Arab and Islamic worlds are not coterminous, the foreign policy preferences of political Islamists and Arab 
nationalists largely reinforce each other. Islam and Arabism both prioritise Arab or Islamic unity over individual reason of state; both insist on economic and cultural autonomy of the Western-dominated world system and both reject the legitimacy of Israel. Nationalist and Islamic identities overlap. Thus, radical Islamic movements such as the Movement of the Islamic Resistance (HAMAS) and Hizbollah are as much manifestations of Arab national resistance to Israel as they are of Islamic resurgence; Islam has become the ideology of transstate terrorist networks that are animated by grievances almost indistinguishable from those of Arab nationalism: the Western presence in the Gulf, the victimisation of Iraq, the Palestine cause.

To be sure, Islamic movements have not, even where Islamists managed to gain access to the levers of power (as in Turkey in 1997) or amassed influence in the legislature (as in Jordan, Kuwait, Morocco, Yemen), been able to force a significant Islamisation of the foreign policy of states. Yet, given the continued legitimacy deficits of the individual states and their inability to find a credible legitimising substitute for Arabism or Islam, state elites still need to be seen to defend Arab-Islamic norms in the face of a public now aroused by Islamic rather than Pan-Arab movements. Even if regimes can now more easily weather dissent in the streets than hitherto, there is still a legitimacy cost to be paid for openly violating such norms and in certain circumstances Islamic activists have been able to call leaders to account for that; arguably the assassination of Sadat was in part for his separate peace with Israel while the Islamic rebellion against Asad's Syria was in part a result of the legitimacy loss suffered by the regime for its intervention in Lebanon against the Palestine Liberation Organisation (PLO), keeper of the Palestine cause (Noble 1991: 53-4). Particularly in time of crisis with Israel or the West, the older generation of Arab nationalists and younger Islamic militants have come together to put pressure on regimes from below and it is chiefly the fear of de-legitimisation at home which forces states to justify, disguise or refrain from policies that affront the Arab-Islamic identity of their populations.

Islamic movements have in a few cases seized state power and in the most significant case, that of Iran, the Islamic regime explicitly sought to export a Pan-Islamic revolution. Iran aimed to create similar Islamic states that would have been expected to pursue similar policies, namely challenging 'world arrogance' --the United States and its regional client regimes - in the name of the oppressed 
(mustaza'fin) of the Muslim and Third worlds (George 1996: 82). Iran's example and encouragement did much to spread Islamic movements and opposition across the region. But early post-Cold War fears of an all-powerful supra-national Islamic threat sweeping away status quo regimes proved unfounded. The export of Islamic revolution was contained, not least by the alignment of the mildly Islamic Gulf states with secular Iraq in the Iran-Iraq war. No secular regime was overthrown; rather, it was Iran's Islamic ideologues who were pushed from power by pragmatists. Although there are now more overtly Islamic states than hitherto, these regimes - in Afghanistan, Iran, Pakistan, Saudi Arabia and Sudan - are too different from each other to constitute a Pan-Islamic axis: they profess different versions of Islamic ideology and are more often than not in open conflict with each other.

At the supra-state level, there is no evidence of a Pan-Islamic 'regime' comparable to Nasserist Arabism, which could enforce agreed norms regarding what constituted an 'Islamic' foreign policy (George 1996: 79-80). There is a Pan-Islamic institution, the Organisation of the Islamic Conference (OIC), but, significantly, its charter acknowledges state sovereignty, it has no power to coordinate common action and it has been paralysed by rivalries, such as that between Iran and Saudi Arabia. Many Muslim countries, encouraged by the OIC, have provided aid to Muslims in conflict with non-Muslims (as in Bosnia and Palestine); but few Muslim states were prepared to take economic or military risks for such causes. The OIC did have some success in articulating a Muslim consensus on international issues that affected the Muslim world. Thus, after the 11 September events, the OIC condemned terrorism but rejected 'any linkage between terrorism and rights of Islamic and Arab peoples, including the Palestinian and Lebanese ... to selfdetermination ... [and] resistance to foreign occupation [which are] legitimate rights enshrined in the United Nations charter' (OIC Qatar communiqué, 10 October 2001 in Murden 2002: 204). Ironically, at the international level, the OIC was a defender of state sovereignty and international law - embracing the principles of the states system as defensive barriers against Western hegemony (Murden 2002: 197-204). But the OIC could hardly be said to constitute an effective Muslim bloc in world politics. In Murden's judgement, it is in the battle for culture in the homes and streets of the Islamic world that Islam is most potent: 'In a world rapidly being 
swallowed by an all-pervasive global system, Islam [is] a diffuse grassroots counter-hegemony' (Murden 2002: 204).

In summary, while decision-makers cannot wholly ignore political Islam in foreign policy making, no Islamisation of foreign policy has resulted. It is, however, probably premature to conclude that political Islam has been tamed by the states system in a way similar to the fate of Pan-Arabism.

\section{Territorial identity and foreign policy in the non-Arab periphery}

Political identity is, of course, constructed and need not necessarily be rooted in either Arab ethno-nationalism or political Islam. The territorial state based on habitation of a common territory - especially where boundaries correspond to some historical memory and equal citizenship rights under a common government could become an alternative or reinforcing basis of identity and legitimacy in the Middle East. In the Arab states, this potential has been retarded by the very limited extent to which citizens have acquired the rights needed to feel the state is 'theirs'.

It is in the non-Arab states where territory has more closely coincided with ethnic-linguistic identity and/or a history of separate statehood that entities approximating territorial nation-states have been consolidated. Turkey and Iran have long histories as separate imperial centres and have constructed modern nations around their dominant ethnic-linguistic cores with considerable success despite the unfinished task of integrating a multitude of minorities, above all the Kurds. Israel's very identity as a state is inseparable from its role as a homeland for Jews, despite its Arab minority and diverse ethnic origins. This more established identity, in turn, has made democratisation less risky, consolidating identification with these states.

These relatively secure identities may be more compatible with state-centric reason of state than are supra-state identities such as Pan-Arabism, but they are not necessarily less revisionist or the policies they inspire less conflictual. Trans-national ideologies, such as Pan-Turkism, Zionism and Islam, have still played important roles in each of the non-Arab states, each is engaged in irredentistinflamed border conflicts with Arab neighbours; and each has, in significant ways, constructed its identity in opposition to that of the Arab core: Israel sees itself besieged by the Arab world and Turkey's modern secularity aims to differentiate it from its Arab-Islamic 
hinterland. Turkey and Israel remain at war with sub-state identity groups - Palestinians, Kurds - which they cannot assimilate and will neither accommodate nor allow to separate. Iran's position is currently more ambivalent. The Persian-Arab cleavage was exacerbated by Pahlavi Iran's aspirations to act as the regional guardian against Arab instability and radicalism. This was superseded after the revolution by an Islamic identity shared with the Arab world that made Iran seek a leadership role there. But Iran's Shi'ism still differentiated it from the Sunni Islam predominant in the Arab world and Iran's leadership claims, based on Islamic paramountcy, were not recognised by the Arab states, except as a threat.

\section{Conclusion}

The incongruity of identity and territory continues to destabilise the politics of the Middle East and to significantly qualify the Westphalian model. While Arab states have consolidated their sovereignty in the face of supra-state ideology, in the making of foreign policy, legitimacy requires their leaders must still balance between the two. Inter-Arab politics arguably remains qualitatively different from 'international' politics. Irredentist conflicts continue to bedevil two near-nation-states, Turkey and Israel. Meanwhile, Iran embraces its communal mosaic and projects its foreign policy under an Islamic banner. 